\title{
Research on Microscopic Displacement Behavior of Periodontium with Load-Displacement Curve Under Dental Occlusion
}

\author{
O正 森田 康之 (九大応研) \\ 松下 恭之 (九大院歯) \\ 正内野 正和 (福岡工技セ) \\ 正 東藤 貢 (九大応研) \\ 正 新川 和夫 (九大応研) \\ 古谷野 潔 (九大院歯)
}
Yasuyuki MORITA, Research Institute for Applied Mechanics, Kyushu University, 6-1 Kasuga-koen, Kasuga, Fukuoka Masakazu UCHINO, Fukuoka Industrial Technology Center
Mitsugu TODO, Research Institute for Applied Mechanics, Kyushu University Yasuyuki MATSUSHITA, Graduate School of Dental Science, Kyushu University Kazuo ARAKAWA, Research Institute for Applied Mechanics, Kyushu University Kiyoshi KOYANO, Graduate School of Dental Science, Kyushu University

\section{1. まえがき}

咬合時における歯周組織, 寸なわち歯牙，歯根膜，歯 槽骨 (顎骨) の変位・変形挙動の解明は, 矯正や歯周病 の原因究明の観点から歯科医学分野において重要な研究 課題の一つである.したがって，以前より様々な見地か らそれに関する研究が行われており，計测手法も多様に 開発されている。しかしながら計測装置の空間的制約な どにより，歯周組織の局所的な変位量・ひずみである一 点計測しか行えていない. したがって現状では，この一 点計測による変位情報とロードセルによる荷重情報から 荷重一変位曲線を構成し, 咬合時における歯周組織の変 位・変形挙動を推測しているに過ぎない，すなわち，以 前の研究により, 歯周組織の荷重一変位曲線は咬合の初 期段階で変位が急激に増加し, その後, 荷重が急激に増 加するという二相性が指摘されている(1),(2). しかし，そ の特徴を変位・変形分布と関連付けた研究はない.

そこで本研究では, 咬合時における歯周組織の荷重一 変位曲線を得るとともに，デジタル画像相関法を用いて 歯周組織の変位・変形挙動の可視化を試み, 荷重一変位 曲線と変位・変形分布の関連付けを試みた。

\section{2. 実験方法}

2. 1 デジタル画像相関法 デジタル画像相関法は, 被測定物表面の固有に存在するパターン，あるいはスプ レー塗料などの噴霧により意図的に作成したランダムパ ターンを利用する. 被测定物の変位前後を CCD カメラ などで撮影し, 得られた変位前後のデジタル画像の輝度 值分布を比較することにより, 被測定物表面全体の変位 ベクトルを計測することが可能な方法である，変位量と 変位方向は変位前の画像中の任意の位置を中心とする小 さい画素領域（サブセット: $N \times N$ 画素）を基準として, 変位後の画像より最も相関の良い画素領域を求め, その 中心を変位後の移動位置とする. 相関值 $C_{R}$ を求める方法 として使用した残差最小法の式を以下に示す.

$$
C_{R}(X+u, Y+v)=\sum_{i=-M}^{M} \sum_{j=-M}^{M} I_{d}(X+u+i, Y+v+j)-I_{u}(X+i, Y+j)
$$

ここで, $I_{u}(X, Y), I_{d}(X+u, Y+v)$ はそれぞれ変位前後の画像 光強度を示し, $X, Y$ はサブセットの中心座標, $u, v$ はそ れぞれ $x, y$ 方向への移動量である. また， $N=2 M+1$ で ある. 式(1)の総和が最小になる位置がそのサブセットの 中心が移動した位置の最近接画素となる。しかしながら 式(1)により得られた画素の位置が, 必ずしも最も高い相 関値を得るとは限らない。すなわち，実際の移動量は画 素の整数倍とはならないため，画素間に相関のピークが 存在することが一般的である。 そのため画素間の補間を 行う必要があり，それを考慮した相互相関法の式を次に
示す.

$$
C_{P}(X+u, Y+v)=\frac{\sum_{i=M j=M}^{M} \sum_{j=M}^{M} J_{d}(X+u+i, Y+v+j) \times I_{u}(X+i, Y+j)}{\sqrt{\left(\sum_{i=M}^{M} \sum_{j=M}^{M} l_{d}(X+u+i, Y+v+j)\right)^{2} \times\left(\sum_{i=M}^{M} \sum_{j=M}^{M} l_{u}(X+i, Y+j)\right)^{2}}}
$$

補間方法は，最近接画素の前後の画素で式(2)より得られ た相関值を用いて二次曲線近似による補間を行い，二次 曲線の極大值を最も相関の良い位置とした. 式(2)は式(1) に比べて計算に時閒がかかる反面，画素間を補間する場 合にはさらに良い相関が得られる利点をもつ。

2. 2 試験片可及的に生体に近い状態を実現する ため，二〜三日前に食肉用としてと畜されたブタの頭蓋 骨を使用した．頭蓋骨から下顎骨を分離し，低速精密切 断機（BUEHLER 社製 ISOMET）を用いて，後臼歯・歯 根膜・歯槽骨からなる厚さ $2 \mathrm{~mm}$ の試験片を作製した。 試験片の一例を図 1 に示す．後臼歯と歯槽骨は，歯根全 域で厚さ数十〜数百 $\mu \mathrm{m}$ の歯根膜と呼ばれる線維性結合 組織により接着されている。 なお切り出した試験片は, 咬合試験を行う直前まで生理食塩水に浸け, 乾燥を防い だ.

2. 3 実験手順咬合機能を模擬した圧縮試験に関 しては, Gathercole ${ }^{(3)} の$ 手法に做ったが, デジタル画像相 関法を適用するため下記の手順で行った. (i) 生理食塩水 から試験片を取り出し，表面の水分をデジタル画像相関 法に用いるスプレー塗料が塗布できる程度に乾燥させる. (ii) スプレー塗料の噴霧により試験片表面にランダムパ

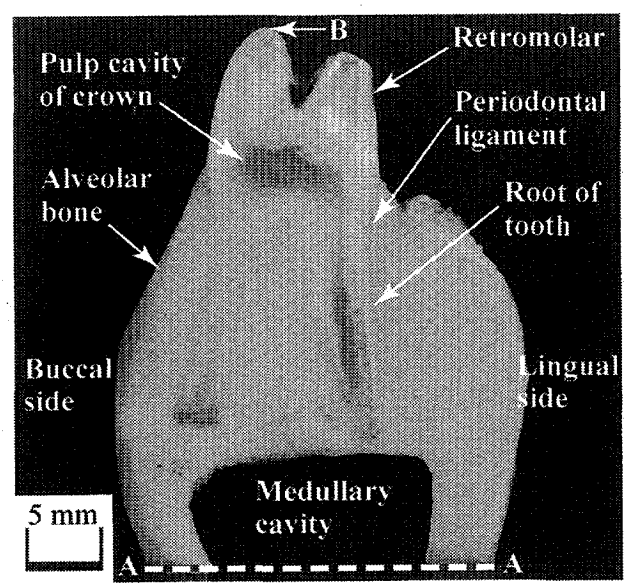

Fig. 1 Periodontium structure. 


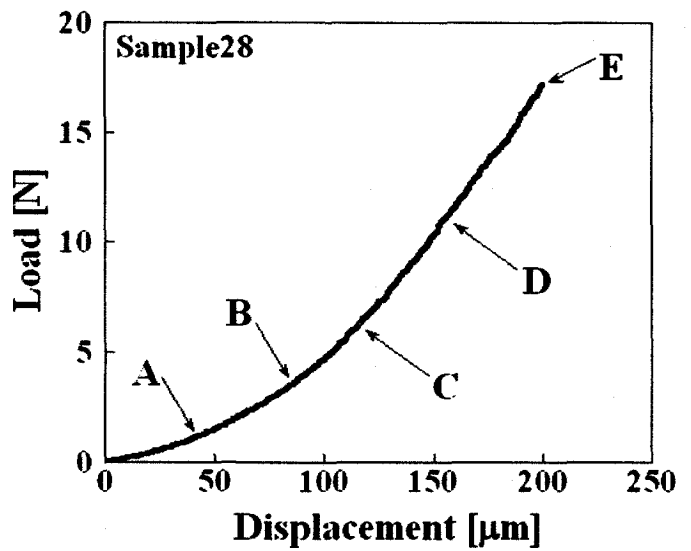

Fig. 2 Load-displacement curve.

ターンを形成する. (iii) 試験片の咀腔周辺の顎骨をバイ スにより固定し（図 1 の破線 $\mathrm{A}$ ), 小型卓上試験機（島津 製作所製 EZ Test) に設置する. (iv) 歯冠上端（図 1 の 点 B）に圧縮荷重を付与する. (v) CCD カメラにより変 位画像を撮影する.

これまでの研究により単一の後且歯に作用する咬合 荷重は明らかになっているが, 今回のような薄片の後臼 歯試験片に作用する実際の咬合荷重は不明である。した がって本研究では，試験機による強制変位を付与するこ とにより咬合荷重を負荷した. その押し込み量は $200 \mu \mathrm{m}$

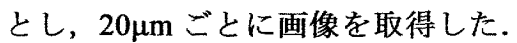

\section{3. 実験結果}

咬合試験により得られた荷重一変位曲線の一例を図 2 に示す．横軸が強制変位の值, 縦軸がその時の荷重を表 している.約 $100 \mu \mathrm{m}$ 程度までは荷重が緩やかに増加し ているのに対し，それ以降は荷重が急激に増加しており， まえがきで述べた荷重一変位曲線の二相性が実験でも得
られていることがわかる。

図 2 に示す点 $\mathrm{A} \sim \mathrm{E}$ における変位分布を図 3 および図 4 に示す. 図 3 は歯軸方向である $y$ 方向の変位分布を示 しており，白色になるほど下方向の変位分布が大きいこ とを意味する.また図 4 は $x$ 方向の変位分布を示してお り，白色になるほど右方向の変位分布が大きいことを意 味する。まず歯軸方向である $y$ 方向に注目する．白黒印 刷の関倸により図 3 からでは若干わかりにくいかもしれ ないが, (a)〜 (b)に示す $80 \mu \mathrm{m}$ 程度までは後臼歯のみ変位 しているのに対し, (c)〜 (e)と押込み量が増加するにつれ， 歯槽骨が変形していることがわかる．すなわち咬合の初 期段階では，歯槽骨と歯根膜の閒に介在する歯根膜が大 きく変形することにより，変位のみが大きく増加してい る. 一方, 次の咬合段階では, 歯槽骨が変形することに より，荷重が急激に増加することがわかる.

また，図 4 に示す $x$ 方向の変位分布では，咬合が進行 するにつれ，頬側の歯槽骨が大きく後田歯の方向に変位 していることを示している．これは，咬合による後田歯 の大きな変位により，歯槽骨と後田歯の間に大きな間隙 が開かないよう歯根膜が歯槽骨を引っ張っていると推測 できる。

\section{4. まとめ}

咬合時における歯周組織の荷重一変位曲線を得ると ともに, デジタル画像相関法を用いて歯周組織の変位・ 変形挙動を可視化し, 荷重一変位曲線と歯周組織の変 位・変形挙動の関連付けた.

\section{参考文献}

(1) Parfitt G.J., J. Dent. Res., 39-3, (1960), 608-618.

(2) Berkovitz, B.K.B, Moxham B.J. and Newman H.N., The Periodontal Ligament in Health and Disease 2nd Edition, (1995), 215-241, Mosby-Wolfe.

(3) Gathercole L.J., Archs. Oral Biol., 32-4, (1987), 249-255.

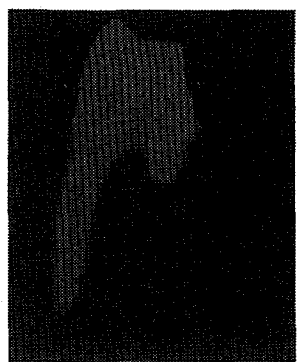

(a) $40 \mu \mathrm{m}$ intrusion Point $A$ in Fig. 2 $\underset{\forall, v}{ }$

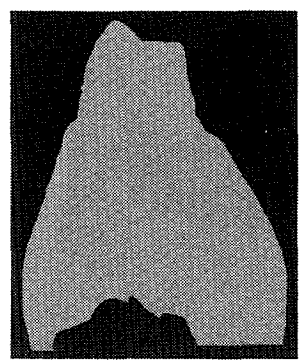

(a) $40 \mu \mathrm{m}$ intrusion Point A in Fig. 2 $\rightarrow-x_{s} u$ $\sqrt{y, v}$

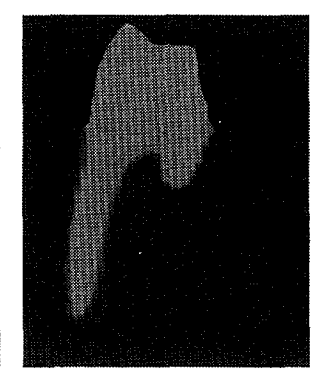

(b) $80 \mathrm{um}$ intrusion Point B in Fig. 2

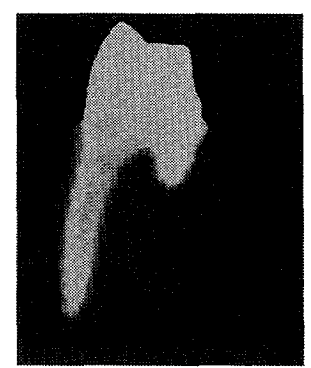

(c) $120 \mu \mathrm{m}$ intrusion Point C in Fig. 2

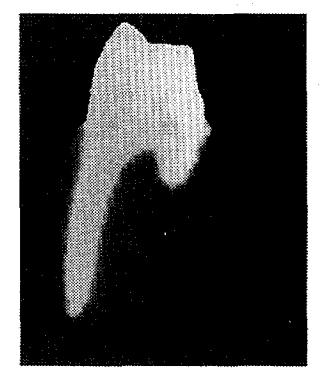

(d) $160 \mu \mathrm{m}$ intrusion Point $\mathrm{D}$ in Fig. 2

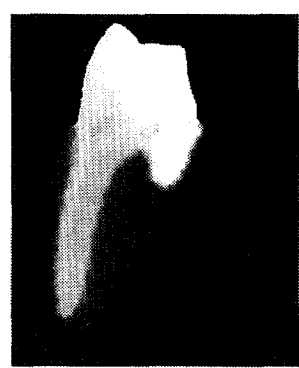

(e) $200 \mu \mathrm{m}$ intrusion Point E in Fig. 2

Fig. $3 v$-displacemnt field of the fresh periodontium specimen.

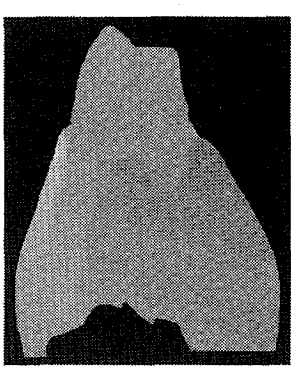

(b) 80 um intrusion Point B in Fig. 2

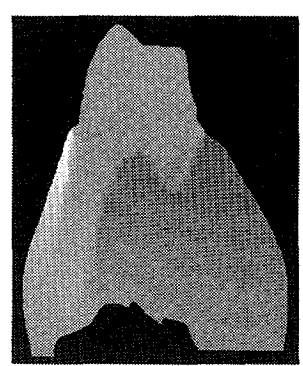

(c) 120 um intrusion Point C in Fig. 2

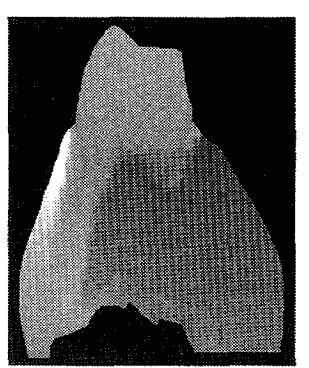

(d) $160 \mu \mathrm{m}$ intrusion Point $D$ in Fig. 2
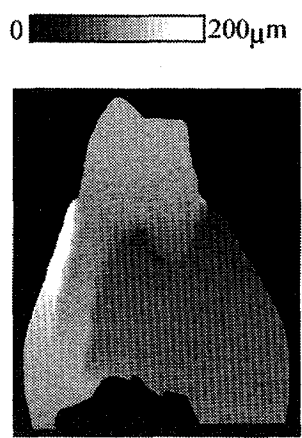

(e) $200 \mu \mathrm{m}$ intrusion Point E in Fig. 2

Fig. $4 u$-displacemnt field of the fresh periodontium specimen.

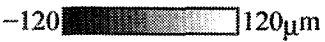

